\title{
COVID-19 Kısıtlamaları Sürecinde Üniversite Öğrencilerinde Sosyal Medya Bağımlılığı ve Temel Psikolojik İhtiyaçlar Arasındaki îlișkinin İncelenmesi
}

\author{
Examining the Relationship Between Social Media Addiction and Basic \\ Psychological Needs in University Students During COVID-19 Restrictions
}

\author{
(1) Illhan BOZKURT ${ }^{1}$, (1) Öznur BOZKURT ${ }^{2}$ \\ ${ }^{1}$ Sakarya Eğitim ve Araștırma Hastanesi, Sakarya, Türkiye \\ ${ }^{2}$ Düzce Üniversitesi İșletme Fakültesi, Düzce, Türkiye
}

\section{Öz}

Amaç: Bu çalıșmada, COVID-19 salgın sürecinde üniversite öğrencilerinin sosyal medya bağımlılığı düzeyi ile temel psikolojik ihtiyaçlarının karşılanma düzeyi arasındaki ilişkinin incelenmesi amaçlanmıștır.

Yöntem: Çalışmada nicel araştırma yöntemi kullanılmış ve bağımlı ve bağımsız değişkenlerin arasındaki ilișki, korelasyonel desen tercih edilerek incelenmiştir. Bir kamu üniversitesinde lisans eğitimi alan öğrenciler araştırmanın evrenini oluşturmuştur. Bu evrenden kolayda örneklem yöntemi ile 508 kişilik örneklem oluşturulmuştur. Araştırma verilerinin toplanması için; Sosyodemografik Veri Formu, Üniversite Öğrencileri Temel İhtiyaçlar Ölçeği (ÜÖTiÖ) ve Sosyal Medya Bağımlılığı Ölçeği (SMBÖ-YF) kullanılmıştır.

Bulgular: Sosyal medya bağımlılığı ve temel psikolojik ihtiyaçların karşılanma düzeyi sosyodemografik değişkenlere ve sosyal medya kullanım alıșkanlıklarına göre farklılașmaktadır. Ayrıca katılımcılar COVID-19 salgın sürecinde, sosyal medya kullanımlarının arttığını ifade etmișlerdir. Bu süreçte sosyal medya kullanım sürelerinin arttığını belirten katılımcıların, diğer katılımcılara göre anlamlı olarak daha yükse sosyal medya bağımlılık düzeyi gösterdikleri belirlenmiştir.

Sonuç: Bazı temel psikolojik ihtiyaçların yeterince karşılanmaması sosyal medya bağımlılığı düzeyini artırırken; yeterince karşılanması ise azaltmaktadır. Salgın sürecinde üniversite öğrencilerinin sosyal medya kullanım oranları artmıştır. Bu süreçte sosyal medya kullanımı artanların sosyal medya bağımlılığı düzeyi de yüksek bulunmuștur.

Anahtar kelimeler: Sosyal medya bağımlılı̆̆ı, psikolojik ihtiyaçlar, üniversite öğrencileri

\section{Abstract}

Objective: The aim of this study was to examine the relationship between the level of social media addiction of university students and the level of meeting their basic psychological needs during the COVID-19 epidemic process.

Method: Relationships between dependent and independent variables were examined in the study. Therefore, quantitative research method was used. Correlational design was preferred while creating the research design. Students who received undergraduate education at a public university formed the universe of the research. A sample of 508 person was created from this universe by the convenience sampling method. For the collection of research data; Sociodemographic Data Form, Social Media Addiction Scale (SMAS-SF) and University Students Basic Needs Scale (USBNS) were used. Results: Social media addiction and the level of meeting basic psychological needs differ according to sociodemographic variables and social media usage habits. In addition, the participants stated that their use of social media increased during the COVID-19 epidemic process. It was determined that the participants, who stated that the duration of their use of social media increased in this process, showed a significantly higher social media addiction level than the other participants.

Conclusion: While some basic psychological needs are not adequately met, the level of social media addiction increases, while meeting them adequately decreases it. Social media usage rates of university students have increased during the epidemic process. In this process, the social media addiction level of those who increased their use of social media was also found to be high.

Keywords: Social media addiction, psychological needs, university students 


\section{Giriş}

Günümüzün önemli kitle iletişim araçlarından biri haline gelen sosyal medyanın kullanımı özellikle gençler arasında hızlı bir artış göstermektedir. Öyle ki, 2004 yılında kullanıma sunulan ilk sosyal medya uygulaması Facebook, yayına bașladıktan sadece bir yıl sonra dünya genelindeki üniversite öğrencilerinin \%85'inden fazlası tarafından kullanıımaya bașlanmıștır (1). Son 10 yıl içinde ortaya çıkan birçok yeni sosyal medya uygulaması ile birlikte insanlar artık; eğlence, sosyal ilișki kurma gibi birçok psikolojik intiyacını karşılamak için de sosyal medyaya yönelmektedir (2). Internet kulanım istatistiklerine göre; internet kullanıcılarının \%63'lük kısmı aktif olarak sosyal medyayı da kullanmaktadır. Covid-19 salgını sürecinin yașandığı 2020 yılında sosyal medya kullanıcılarının sayısı, son 3 yııın en hızı arıısıını göstermiștir. Bu dönemde dünyadaki sosyal medya kullanıc sayısı \%13'lük bir artıșla (490 milyon kiși) 4,20 milyara yükselmiștir. Türkiye'de ise bu sayı \%11'lik artışla (6 milyon kişi) 60 milyona ulaşmıştır (3).

Internet teknolojilerindeki hızlı gelişmelere paralel olarak değişen intiyaçlar, insan davranışlarının da çeșitlenmesine yol açmaktadır. Bu durum ise, var olan psikopatolojilerin yeni örüntüler kazanmasına ya da bazı yeni psikopatolojilerin ortaya çıkmasına neden olabilmektedir (4). Yapılan bir dizi araștırma, günümüzde artan problemli sosyal medya faaliyetleriyle, internet kaynaklı bağımlılıkların ilișkisine dikkat çekmektedir (5). Özellikle sosyal medya paylașımlarına yapılan beğeni gibi olumlu bildirimlerin sağladığı psikolojik doyum veya bașka bazı nedenlerle sosyal medyaya artan miktarlarda giriș yapılması (6) ve bu döngüye giren kișilerin sosyal medya kullanımlarının zaman içinde problemli hale dönüșmesi, sosyal medya bağımlılığı konusunun ele alınılmasını zorunlu hale getirmiștir (7). Başlangıçta; sosyal ilişkileri sürdürmek, yeni kişilerle tanıșmak, kendini ifade etmek ya da eğlenmek gibi ihtiyaçları karșılanmak amacıyla bașlayan sosyal medya kullanımı, bir süre sonra sağlıksız bir kullanım şekline dönüșebilmektedir $(8,9)$. Kontrolden çıkan sosyal medya kullanımı, kișilerin diğer yașam görevlerini engelleyecek șekilde problemli hale dönüștüguünde ise sosyal medya bağımlılı̆̆ından söz edilmektedir (10).

Internet temelli bağımlılıklarla ilgili yapılan birçok araștırmada, sosyal medya bağımlıı̆̆ı kavramı önemli bir yer tutmaktadır. Bu araştırmalar; Amerikan Psikiyatri Birliği'nin Ruhsal Bozuklukların Tanısal ve Sayımsal El Kitabının 5. baskısında (DSM-5) yapılan tartışmalarda internet oyun oynama bozukluğu tanısı için önerilen; kaygı, tolerans ve kontrol kaybı gibi birçok bağımlıık kriterinin, sosyal medya bağımlılığı için de geçerli olduğuna dikkat çekmektedir. DSM-5’te sadece "Internette Oyun Oynama Bozukluğu" ele alınmıs ve ileri düzeyde araștırmalar gerektiren durumların sınıflandırıldığı 3. bölümde yer almıștır (11). Sosyal medya bağımlılı̆ı ise DSM-5’te yer almamıştır. İnternet tabanlı bağımlılıkların yalnızca internet oyun oynama bozukluğu ile sınırlandırılması, internetle bağlantılı diğer davranışsal bağımlıııların gözden kaçırılması riski taşımaktadır.

Internet tabanlı bağımlııklar konusunda standart bir tanımın olmayışı nedeniyle (12) sosyal medya kullanımı ile ruh sağlığı arasındaki ilişkiyi inceleyen araştırmalarda; sosyal medya bağımlılığı, problemli sosyal medya kullanımı ve kontrolsüz sosyal medya kullanımı gibi çeşitli terimler kullanılmaktadır (7). Alan yazında en sık kullanılan ve araştırmacılar tarafından da önemli ölçüde kabul gören tanıma göre, sosyal medya bağımlılı̆̆ı: Kişinin Sosyal medya uygulamalarına girmek için karşı konulması güç bir istek duyması, sosyal medyaya aşırı düşkün olması ve burada gerçekleştirilen aktivitelerin gerçek hayattaki sosyal faaliyetlerini, iş ve kișiler arası ilișkilerini bozmasıdır (13).

İnsanların gerçek hayatta yeterince doyum sağlayamadığı psikolojik intiyaçlarına sosyal medya aracılığı ile problemli şekilde doyum sağlamaya çalışması sosyal medya bağımlııı̆ının önemli nedenlerinden biri olarak düşünülmektedir. Kullanımlar ve doyumlar kuramına göre, insanlar psiko-sosyal intiyaçlarını tatmin etmek için çeșitli teknolojik araçlara yönelirler ve bazı intiyaçlarına bu araçlar vasıtasıyla doyum sağlarlar (14). Psikolojik intiyaçlara doyum sağlamaya yönelik beklentiler, kişilerin sosyal medyaya yönelmelerinin en önemli nedenlerinden biridir (15). Bu nedenle sosyal medya ortamlarında ortaya konulan davranışlarla bazı psikolojik ihtiyaçlara doyum sağlanmaya çalışıldığı söylenebilir $(8,9)$. Psikolojik intiyaçlar bu yönüyle, sosyal medya bağımlılı̆ı ile ilișkili olabilecek önemli bir faktördür.

Iç̧ine doğdukları dijital ortama çabuk adapte olan ve dijital yerliler olarak da tanımlanan Z kuşağı gençlerinin sosyal medyaya oldukça fazla ilgi göstermeleri sosyal medya bağımlılığı için önemli bir risk faktörü olarak görülmektedir (16). Sosyal medya bağımlılığının eğitim düzeyi yüksek ve genç kişilerde daha fazla görüldügüne yönelik bazı araştırma bulguları da bunu doğrulamaktadır (17-19). Sosyal medyanın kullanım şekli ve miktarı, hissedilen ihtiyaçların niteliğine ve tatmin olma derecesine göre farklılaşmaktadır. Gençlerin internet tabanlı uygulamalara karșı yönelișinin sağlıklı veya problemli olması, bu eylemlerden dolayı doyum sağladıkları ihtiyaçlar kümesine ve bu ihtiyaçların nasıl karşıladığına göre değişmektedir $(20,21)$.

Psikolojik ihtiyaçlarla ilgili birçok çalıșma yapılmıștır. William Glasser'in geliștirdiği Seçim Kuramına göre (Choice Theory), insan davranışları onda doğuştan var olan; hayatta kalma, özgürlük, güç, eğlence ve ait olma-sevgi ihtiyaçlarının karșılanmasına yönelik olarak ortaya çıkmaktadır. Bu beş temel intiyaçtan biri olan hayatta kalma, en temel ve fizyolojik ihtiyaçken, diğerleri ise psikolojik intiyaçlardır. Psikolojik intiyaçların yeteri kadar giderilmesi, insanın iyi olma halini artırmakta, yeteri kadar karşılanamaması ise davranış sorunlarına yol açmaktadır 
(3). Glasser insanın dört temel psikolojik ihtiyacını şu şekilde açıklanmaktadır:

Sevme ve ait olma ihtiyacı; Glasser'e göre insanlar, ihtiyaçlarını giderebilmek için bașkalarına intiyaç duyarlar (22). En az temel biyolojik ihtiyaçlar kadar önemli olan bu intiyacın (23) yeterince karșılanamaması yalnızık hissine (24) ve bazı olumsuz davranışlara zemin hazırlar (25). Güçlü olma ihtiyacı; prestij kazanma, saygı görme, yarışma, şöhret, seçim yapabilme ve kendini önemli hissetme ile ilgilidir (26). Güç ihtiyacını normal yollardan karșılayamayan bazı insanlar, bağımlılık yapıcı davranıșlara yönelebilmektedirler (27). Özgürlük ihtiyacı; bireyin yaşamını kendi seçimleri ile kontrol edebilme intiyacıdır (28). Insanlar özgürlüklerinin kısıtlandığı ortamlardan uzaklaşırlar (29). Eğlence intiyacı; kișilerin keyifli, zevkli ve neșeli vakit geçirme intiyaçlarını kapsamaktadır (26). Bazı insanlar zevk aldıkları yerlere giderek, bazıları ise internet ya da televizyon yoluyla eğlenirler (30).

Alan yazında psikolojik intiyaçların sosyal medya kullanım alıșkanlıklarıyla ilișkisini araștıran sınırlı sayıda çalışmalar vardır (31). Bu çalışmada; sosyal medya kullanımının yüksek olduğu düșünülen üniversite öğrencilerinin, sosyal medya bağımlılık düzeyi ile temel psikolojik intiyaçlarının karşılanma düzeyi ilișkisi araştıııımıștır. Araștırmanın yapıldığı dönemde, üniversite öğrencilerinin de içinde bulunduğu yaş grubu için sokağa çıkma yasağı, yüz yüze eğitimlerin durdurulması gibi COVID-19 salgın kısıtlamaları uygulanmaktaydı. Bu nedenle araştırmada salgın kısıtlamaları sürecinde üniversite öğrencilerinin psikolojik intiyaçlarının karşılanma düzeyi, sosyal medya kullanım alıșkanlıkları ve sosyal medya bağımlılık düzeyleri üzerinde durulmuștur.

\section{Yöntem}

Araștırma da bağımlı ve bağımsız değișkenler arasındaki ilișkiler incelenmiștir. Bu nedenle nicel araștırma yöntemi kullanılmıștır. Araștırma deseni oluşturulurken korelasyonel desen tercih edilmiștir.

\section{Örneklem}

Araștırmaya Düzce Üniversitesinde eğitim gören gönüllü öğrenciler dahil edilmiștir. Araștırmanın evrenini otuzbin üniversite öğrencisi oluşturmaktadır. Araştırma evreninden olasılıksız örnekleme yöntemlerinden, kolayda örnekleme yöntemi ile örneklem alınmıştır. Örneklem büyüklüğünü belirlemek için \%95 güven aralı̆̆ı kullanıımıștır. Belirli evrende örneklem belirlemek için kullanılan formüle göre örneklem sayısı 379 olarak belirlenmiștir. Çalıșmada 515 üniversite öğrencisine ulașılmıştır. Katılımcılar, en az 4 yıllık bir bölümde okuyan \%65,2’si kız, \%34,8’i erkek öğrenciden oluşmuștur.

\section{İşlem}

Araştırmanın yürütülebilmesi için, 20.05.2020 tarihinde 202014-09 sayı ile İstanbul Gelişim Üniversitesi Etik Kurulu'ndan onay alınmıştır. Araştırma verileri Haziran 2020-Ağustos 2020 tarihleri arasında gönüllü katılımcılara çevrimiçi olarak uygulanan anketler ile toplanmıştır. Örnekleme, Covid-19 salgını sürecinde uzaktan eğitim yöntemi ile ders veren bölüm öğretim elemanları aracılığı ile ulaşılmıştır Araştırmaya katılanlara onam formu veri toplama araçları ile birlikte sunularak onamları alınmıștır. Anketleri tam olarak dolduran toplam 508 katılımcının cevapları değerlendirmeye alınmıştır. 7 katılımcının anket formları ise eksik doldurulması nedeniyle değerlendirmeye alınmamıştır.

\section{Veri Toplama Araçları}

\section{Sosyodemografik Veri Formu}

Katılımcıların sosyodemografik özellikleri ve sosyal medya kullanım alışkanlıklarıyla ilgili verileri elde etmek için araștırmacılar tarafından olușturulmuștur. Toplam 14 sorudan oluşan formda 8 soru sosyodemografik bilgilerle, 6 soru ise sosyal medya kullanım alışkanlıklarıyla ilgilidir. Sosyal Medya Bă̆ımlılığı Ölçeği (SMBÖ-YF): Yetişkinlerin sosyal medya bağımlılığı düzeyini ölçmek amacıyla, șahin ve Yağcı (2017) tarafından geliștirilen 20 maddelik beşli Likert tipi bir ölçektir. Ölçekten alınan toplam puanın yüksek olması, sosyal medya bağımlılığının yüksek olduğu anlamına gelmektedir. Ölçek $p<0,001$ güven aralığında ,937 güvenilirlik katsayısına sahiptir (32). Ayrıca bu çalıșmada yapılan güvenilirlik analizi sonucunda ölçeğin güvenilirliği ,858 olarak bulunmuștur.

\section{Üniversite Öğrencileri Temel Ihtiyaçlar ölçeği (ÜÖTiö)}

Üniversitede okuyan öğrencilerin psikolojik ihtiyaçlarının karşılanma düzeyini ölçmek için, Türkdoğan ve Duru (2012) tarafından geliştirilmiş beşli Likert tipi bir ölçektir. Ölçek öğrencilerin; hayatta kalma, güç, sevgi-ait olma, eğlence ve özgürlük ihtiyacının ne düzeyde karşılandığını ölçen 19 maddeden oluşmaktadır. Her alt ölçek bağımsız olarak da kullanılabilmektedir. Alt boyutlardan alınan puanların yüksekliği, ilgili ihtiyacın yeterli düzeyde karșılandığı anlamına gelmektedir. Ölçeğin psikolojik intiyaçları ölçen dört boyutunun güvenilirlik değerleri: Sevgi-ait olma (,77), güç (,77), özgürlük $(, 75)$ ve eğlence $(, 85)$ 'dir (33). Araştırma kapsamında ölçeğin bu dört boyutu kullanılmıştır ve yapılan analiz sonucunda da güvenilirlik değerleri; Sevgi-ait olma (,89), güç (,75), özgürlük $(, 83)$ ve eğlence $(, 74)$ olarak bulunmuştur.

\section{Veri Analizi}

Araştırma verileri SPSS 22.0 programında; ilişkisel, farklılık ve tanımlayıcı istatistik analizleri yapılarak incelenmiştir. Veri toplama araçları için yapılan güvenilirlik testlerinde ölçme 
araçlarının \%70 güven aralığının üzerinde olduğu bulunmuştur. Yapılan normallik testi sonucuna göre de veri setinin basıklık ve çarpıklık değerleri literatürde genel kabul gören -1,50 ile +1,50 arasında bulunmuştur. Normal dağılım gösteren veriler buna uygun olarak analiz edilmiștir. Yapılan tanımlayıı analizlerde araştırmanın değişkenlerinin genel ortalama, güvenilirlik ve normallik analizleri ile katılımcıların sosyodemografik verileri ve sosyal medya kullanım alıșkanlıklarına yönelik analizler yapılmıştır. Illişkisel analizlerde ise değişkenler arasındaki ilișkilerin belirlenmesi için korelasyon ve regresyon analizleri yapılmıştır. Değișkenlerin, demografik özelliklere ve öğrencilerin sosyal medya kullanım alışkanlıklarına göre farkııaşıp farklılașmadığını belirlemeye yönelik olarak ise bağımsız grup t testi ve anova analizleri yapılmıștır. Analiz sonuçlarının değerlendirilmesinde anlamlılık $p<0,05$ kabul edilmiștir.

\section{Bulgular}

Araștırmanın katılımcıları, \%65,2'si kadın, \%34,8'i erkek olmak üzere toplam 508 üniversite öğrencisinden olușmuștur. Katılımcıların \%58,7'si 21-23 yaş aralı̆̆ında, \%43,8'i ailenin ilk çocuğu ve \%31,1'i bir kardeșe sahiptir. Okunan sınıf açısından ise çoğunluğu $(\% 36,4) 3$. sınıf öğrencileri olușturmaktadır. Katılımcı öğrencilerin \%64,6’sının aylık geliri orta düzeydedir (Tablo 1).

Üniversite öğrencilerinin sosyal medya kullanım alışkanlıklarına bakıldığında; araştırmaya katılan öğrencilerin \%77,4'lük kısmı sosyal medyaya sadece mobil cihazlarla girmektedir. Katılımcıların \%48,9'luk kısmı 4 ila 6 yıldır, \%48,3'ü ise 7 ve daha fazla yıldır sosyal medya kullanmaktadır. Sosyal medyanın günlük kullanım süresi açısından ise, sosyal medyayı 1-3 saat arası kullananların oranı \%48; 4-6 saat arası kullananların oranı $\% 36$, yedi saat ve daha fazla kullananım süresi olanların oranı ise \%8,7'dir. Katılımcıların \%72,3 gibi büyük bir çoğunluğu sosyal medyayı akşam ve gece vakitlerinde kullanmaktadırlar. COVID-19 salgını sürecinde katılımcıların \%82,9'u sosyal medya kullanımının çeșitli derecelerde artıı̆ını bildirmiștir. Bu süreçte en fazla artış \%39.6 ile 2-3 saat olmuștur (Tablo 2).

Katılımcıların sosyal medya bağımlılı̆ı düzeyinin genel ortalaması orta derecededir (2.84). Frekans analizi sonucuna göre ise; \%17,9'unun sosyal medya bă̆ımlılı̆̆ düzeyi yüksek, \%53,3'ünün orta ve \%28,7'sinin ise düșük bulunmuștur. Temel psikolojik ihtiyaçlar açısından, katılımcılar genel olarak ihtiyaçlarının karșılandığını düşünmektedir. En yüksek düzeyde karșılanan psikolojik ihtiyaç sevgi ve ait olma ihtiyacıdır. Bunu; eğlence, güç, özgürlük ihtiyaçları takip etmektedir (Tablo 3). Ayrıca verilerin güvenilirliğine yönelik yapılan analize göre, alpha değeri ,70'in üzerindedir. Tabachnick ve Fidell (2012) normal dağılım için, basıklık ve çarpıklık değerinin -1,5-+1,5 aralığında olması gerektiğini ifade etmektedir (34). Buna göre veriler normal dağılım sergilemektedir (Tablo 3).
Yapılan korelasyon analizi sonucuna göre, eğlence ihtiyacı dışındaki diğer psikolojik intiyaçlar olan; güç, sevgi-ait olma ve özgürlük ile sosyal medya bă̆ımlılığı arasında düșük dereceli ve negatif yönlü bir ilişki olduğu bulunmuştur $(\operatorname{sig} \leq 0,05)$. Bu intiyaçların yeterince karșılanmaması sosyal medya bağımlılığı düzeyini artıırken yeterince karşılanması ise azaltmaktadır (Tablo 4).

Regresyon analizine göre ise, özgürlük ve güç ihtiyacının karșılanma düzeyi katılımcıların sosyal medya bağımlılı̆ını açıklamaktadır. Bir başka ifadeyle, sosyal medya bağımlığı düzeyinde ortaya çıkacak \%15 oranındaki negatif yönlü bir değişim, özgürlük ihtiyacının karşılanma düzeyiyle; \%17'lik negatif değişim ise güç intiyaçlarının karşılanma düzeyiyle açıklanmaktadır. Sevgi-ait olma ve eğlence ihtiyacının karșılanma düzeyine göre ise sosyal medya bă̆ımlılı̆̆ açısından anlamlı bir etkilenme görülmemektedir (Tablo 5).

Katılımcıların sosyal medyayı kullanım sürelerinde COVID-19 pandemisi sürecinde çeșitli düzeylerde artış yaşandığı görülmektedir. Sosyal medya kullanım sürelerinde yaşanan bu artışa paralel șekilde, katılımcıların sosyal medya bağımlılığı

Tablo 1: Katılımcıların sosyodemografik özellikleri

\begin{tabular}{|c|c|c|}
\hline \multicolumn{2}{|c|}{ Sosyodemografik Özellik Değișken } & $\%$ \\
\hline \multirow{2}{*}{ Cinsiyet } & Kadın & $\% 65,2$ \\
\hline & Erkek & $\% 34,8$ \\
\hline \multirow{4}{*}{ Yaș } & 18 ve altı & $\% 3,9$ \\
\hline & $19-20$ & $\% 32,1$ \\
\hline & $21-23$ & $\% 58,7$ \\
\hline & 24 ve üstü & $\% 5,3$ \\
\hline \multirow{3}{*}{ Doğum sırası } & ilk & $\% 43,8$ \\
\hline & Ortanca & $\% 26,3$ \\
\hline & Son & $\% 29,9$ \\
\hline \multirow{4}{*}{ Sinıf } & 1. Sinıf & $\% 34,1$ \\
\hline & 2. Sinıf & $\% 22,8$ \\
\hline & 3. Sinıf & $\% 36,4$ \\
\hline & 4 ve üzeri & $\% 6,7$ \\
\hline \multirow{4}{*}{ Kardeș sayısı } & 0 & $\% 3,7$ \\
\hline & 1 & $\% 31,1$ \\
\hline & 2 & $\% 27,2$ \\
\hline & $\begin{array}{l}3 \\
4 \text { ve üzeri }\end{array}$ & $\begin{array}{l}\% 18,7 \\
\% 0\end{array}$ \\
\hline \multirow{3}{*}{$\begin{array}{l}\text { Aylık harcanabilir gelir } \\
\text { (Harçlık, burs vb.) }\end{array}$} & Düşük & $\% 31,5$ \\
\hline & Orta & $\% 64,6$ \\
\hline & Yüksek & $\% 3,9$ \\
\hline
\end{tabular}


Tablo 2: Katılımcıların sosyal medya kullanım alışkanlıkları

\section{Sosyal medya kullanım alıșkanlığı}

Sosyal medyaya girmek için kullanılan cihaz türü

Sosyal medya kullanım yılı

Sosyal medyada günlük geçirilen süre

Sosyal medyayı gün içinde kullanım zamanları

COVID-19 sürecinde sosyal medya kullanımındaki artıș

\begin{tabular}{|l|l|}
\hline Değișken & $(\%)$ \\
\hline Masaüstü bilgisayar & $\% 0$ \\
\hline Mobil cihaz & $\% 77,4$ \\
\hline Masaüstü+Mobil & $\% 22,6$ \\
\hline 1 yıldan daha az & $\% 2,4$ \\
\hline $1-3$ yıl arası & $\% 10,4$ \\
\hline $4-6$ yıl arası & $\% 43,9$ \\
\hline 7 yıl ve üzeri & $\% 43,3$ \\
\hline 1 Saatten az & $\% 7,3$ \\
\hline $1-3$ saat arası & $\% 47,4$ \\
\hline 4-6 saat arası & $\% 36,6$ \\
\hline 7 saat ve üzeri & $\% 8,7$ \\
\hline Sabah & $\% 1,4$ \\
\hline Öğle & $\% 5,3$ \\
\hline Akşam & $\% 34,1$ \\
\hline Gece & $\% 38,2$ \\
\hline Tüm Gün & $\% 21,1$ \\
\hline Artış olmayan & $\% 17,1$ \\
\hline 0-1 Saat arası & $\% 19,1$ \\
\hline 2-3 Saat arası & $\% 39,6$ \\
\hline 4-5 Saat arası & $\% 15,0$ \\
\hline 6-7 Saat arası & $\% 5,1$ \\
\hline 8 Saat ve üzeri & $\% 4,1$ \\
\hline & \\
\hline
\end{tabular}

Tablo 3: Değișkenlere ait güvenilirlik ve normallik testi ile sosyal medya bağımlılı̆̆ı düzeyi istatistikleri

Değișken N Ort. St. Sapma $\alpha$ Basıklık Çarpıklık

\begin{tabular}{|c|c|c|c|c|c|c|}
\hline Sosyal Medya Bağımlılığı & 508 & 2,84 & 0,625 & 0,858 & 0,082 & $-0,433$ \\
\hline Sevgi ve ait olma & 508 & 4,30 & 0,964 & 0,891 & 1,434 & $-1,427$ \\
\hline Eğlence & 508 & 3,82 & 0,847 & 0,740 & $-0,390$ & $-0,505$ \\
\hline Özgürlük & 508 & 3,63 & 0,958 & 0,834 & $-0,202$ & $-0,539$ \\
\hline \multicolumn{7}{|c|}{ Sosyal Medya Bağımlılığı Oranı } \\
\hline Bağımlılık düzeyi düşük & & & & 146 & 28,7 & \\
\hline Bağımlılık düzeyi orta & & & & 271 & 53,3 & \\
\hline Bağımlılık düzeyi yüksek & & & & 91 & 17,9 & \\
\hline
\end{tabular}

düzeyinde de artış yașanmıștır. En yüksek düzeyde bağımlılığı olanların, salgın sürecinde sosyal medya kullanımının 8 saat ve daha fazla arttı̆̆ını bildirenler olduğu görülmektedir. Genel olarak değerlendirildiğinde, COVID-19 salgını sürecinde üniversite öğrencileri sosyal medyada geçirdikleri sürenin arttığını belirtmiștir ve bu artışa paralel olarak sosyal medya bağımlılık düzeylerinin de yükseldiği görülmektedir. Temel psikolojik ihtiyaçların karșılanma düzeyi ise bu dönemde farklılașmamıștır (Tablo 6).

Sosyal medya bağımlılığının düzeyi, kullanım alışkanlıklarına göre farklılık göstermektedir. Bağımlılık düzeyleri yüksek olan öğrenciler, sosyal medya uygulamalarını gün boyu ve diğerlerine göre daha fazla kullanmaktadırlar. Sosyal medyanın günlük kullanım süresi arttıkça bağımlılığın düzeyi de artmaktadır. 
Tablo 4: Temel psikolojik ihtiyaçların karșılanma düzeyi ve sosyal medya bağımlılığı ilișkisi

\section{Sosyal Medya Bağımlılığı Tolerans VIF}

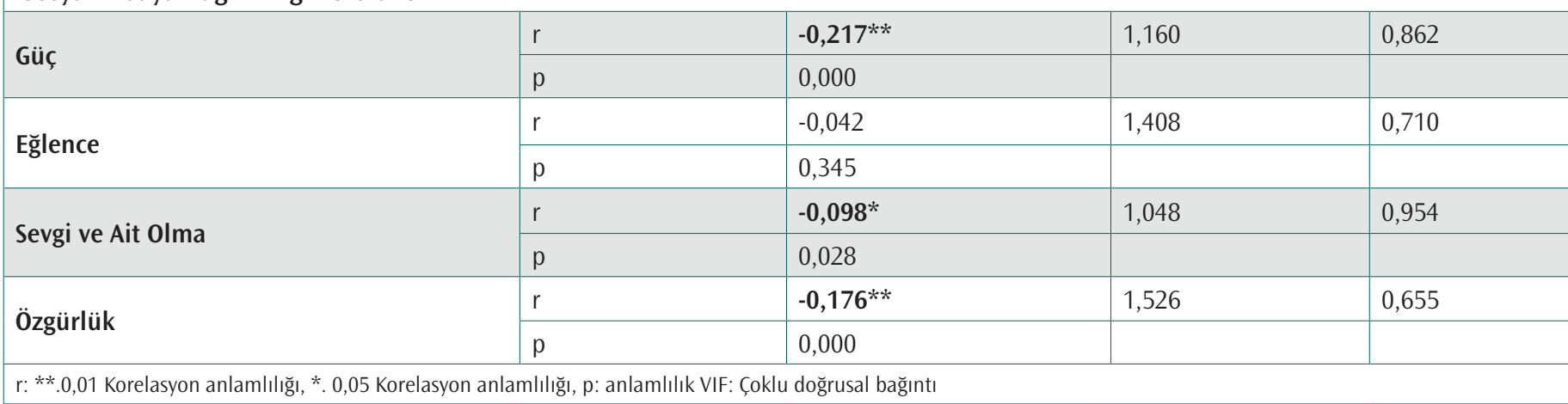

Tablo 5: Temel psikolojik ihtiyaçların karșılanma düzeyinin sosyal medya bağımlılığına etkisi

\begin{tabular}{|l|l|l|l|l|l|}
\hline \multicolumn{2}{|l|}{ Model Standart Olmayan Katsayılar } & \multicolumn{3}{l|}{ Sandart Katsayılar } \\
\hline & $\mathrm{B}$ & Std. Hata & Beta & $\mathrm{t}$ & $\mathrm{p}$ \\
\hline (Sabit) & 3,634 & 0,188 & & 19,312 & 0,000 \\
\hline Güç İhtiyacı & $-0,151$ & 0,039 & $-0,178$ & $-3,841$ & 0,000 \\
\hline Eğlence İhtiyacı &, 070 & 0,038 & 0,095 & 1,862 & 0,063 \\
\hline Sevgi-Ait Olma İhtiyacı & $-0,037$ & 0,029 & $-0,057$ & $-1,301$ & 0,194 \\
\hline Özgürlük İhtiyacı & $-0,098$ & 0,035 & $-0,151$ & $-2,832$ & $\mathbf{0 , 0 0 5}$ \\
\hline
\end{tabular}

Bağımlı Değișken: Sos. Medya Bağımlıı̆ı̆; Adj.R2:0,059, D.Watson: 1,963, df: 4, F: 89,25, B: regresyon ağılı̆̆ı, t: grupların ortalama farkı, p: anlamlılık, Beta: regresyon katsayısı, Adj.R²: düzeltilmiş regresyon katsayısı, D. Watson, otokorelasyon testi, df: serbestlik derecesi, F: varyans eșitliği

Tablo 6: Temel psikolojik ihtiyaçların karșılanma düzeyi ve sosyal medya bağımlılığının, COVID-19 Sürecinde sosyal medya kullanımındaki artıșa göre farklılığı

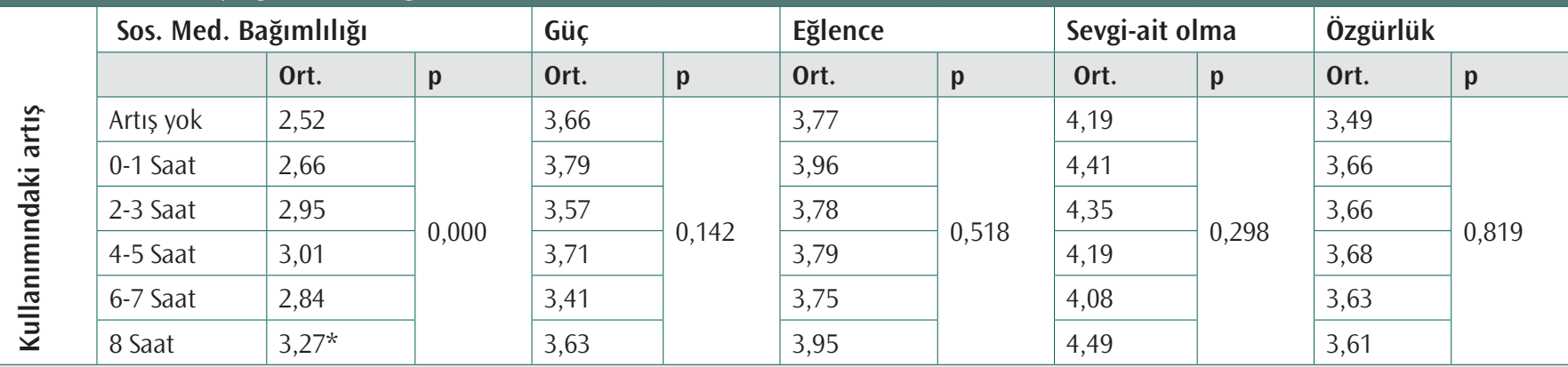

*Farkın olduğu grup, p: anlamlılık, Ort: ortalama

Günlük bir saatten az sosyal medya kullanan kişilerin bağımlııık düzeyi daha düşüktür. Psikolojik ihtiyaçların karşılanma düzeyinin de sosyal medya kullanım alıșkanlıklarına göre farklılaștığı görülmektedir. Sosyal medyayı sabah saatlerinde yoğun kullananların güç ihtiyacını karşılama düzeyinin daha düşük olduğu, öğle saatlerinde kullananların ise eğlence ve özgürlük ihtiyacının karșılanma düzeyinin daha yüksek olduğu görülmektedir. Ayrıca güç ihtiyacı yeterince karșılananlar, sosyal medyada daha az zaman geçirmektedir (Tablo 7).

Bağımsız grup t testi sonucuna göre, sosyodemoğrafik değișkenler açısından değerlendirme yapıldığında, kadınların sosyal medya bağımlılığı erkeklere göre daha yüksek bir ortalamaya sahiptir. Psikolojik ihtiyaçların karșılanma düzeyine göre ise cinsiyet açısından farklııı bulunmamaktadır. Anova testi sonucuna göre de yaşın artmasıyla birlikte, sosyal medya bă̆ımlılı̆̆ azalmakta; güç ihtiyacının karşılanma düzeyi ise artmaktadır. Son sınıftaki öğrencilerin sosyal medya bağımlılı̆̆ı ve eğlence ihtiyaçlarının karşılanma düzeyi daha düşüktür. Dört ve üstünde kardeși olanların sosyal medya bağımlılığı ve özgürlük ihtiyacının karşılanma düzeyi daha düşüktür. Aylık gelir arttıkça; güç, sevgi-ait olma ve özgürlük ihtiyaçlarının karşılanma düzeyi de artmaktadır. Orta gelire sahip olanların ise eğlence intiyacı daha fazla karșılanmaktadır (Tablo 8). 


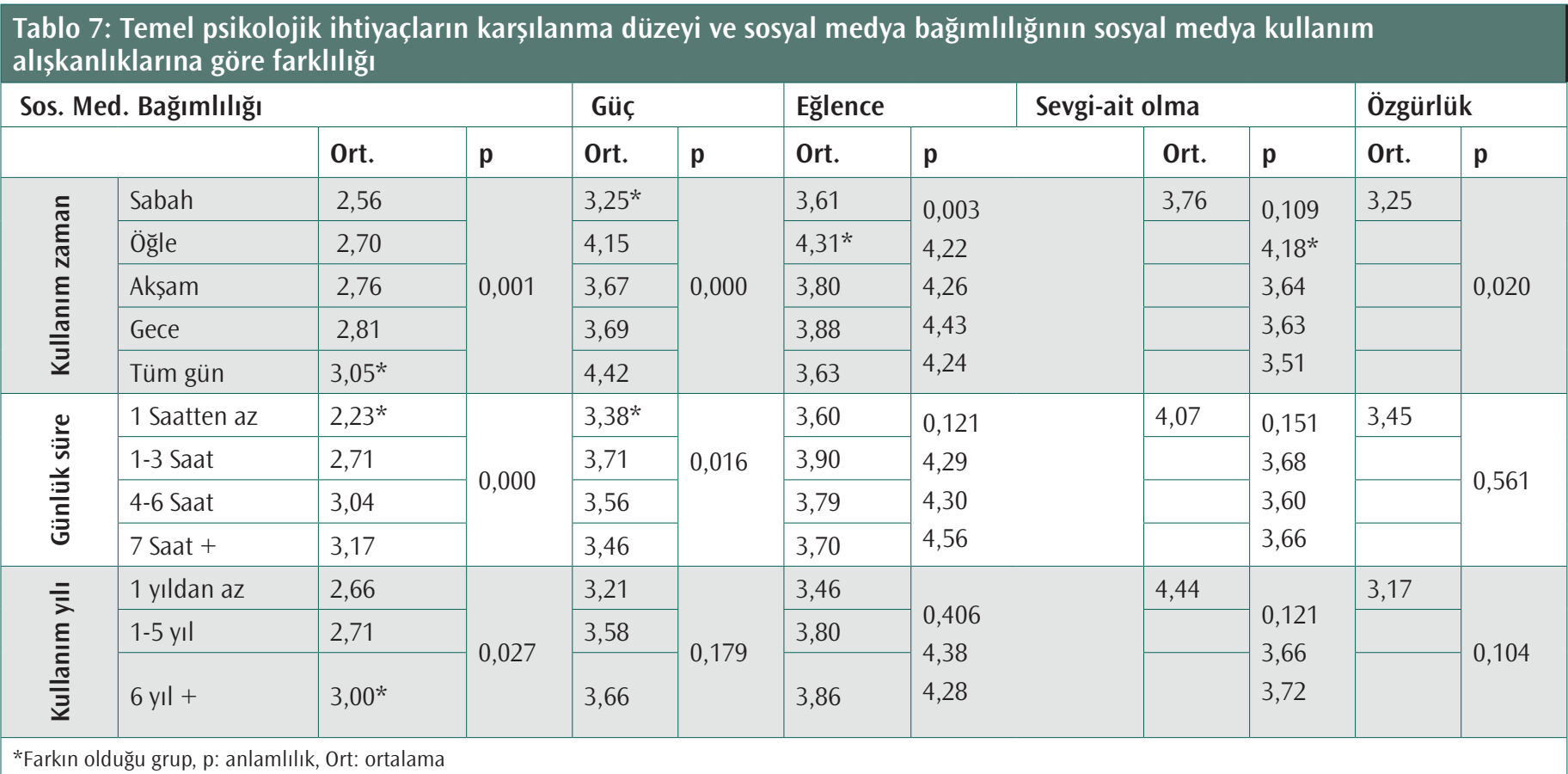

\section{Tablo 8: Temel psikolojik ihtiyaçların karșılanma düzeyi ve sosyal medya bağımlılığının sosyodemografik özelliklere göre} farkı

\begin{tabular}{|c|c|c|c|c|c|c|c|c|c|c|c|}
\hline \multicolumn{4}{|c|}{ Sos. Med. Bağımlılığı } & \multicolumn{2}{|l|}{ Güç } & \multicolumn{2}{|c|}{ Eğlence } & \multicolumn{2}{|c|}{ Sevgi -ait olma } & \multirow{2}{*}{\multicolumn{2}{|c|}{$\begin{array}{l}\text { Özgürlük } \\
\text { Ort. p }\end{array}$}} \\
\hline & & Ort. & p & Ort. & p & Ort. & p. & Ort. & $\mathbf{p}$ & & \\
\hline \multirow[b]{3}{*}{ 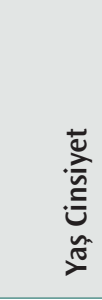 } & Kadın & 2,88 & 0,026 & 3,67 & 0,351 & 3,82 & 0,967 & 4,33 & \multirow{2}{*}{0,422} & \multirow{2}{*}{$\begin{array}{l}3,58 \\
3,73\end{array}$} & \multirow[t]{2}{*}{0,105} \\
\hline & Erkek & 2,75 & & 3,60 & & 3,82 & & 4,25 & & & \\
\hline & $\begin{array}{l}18 \text { ve altı } \\
19-20 \\
21-23 \\
24+\end{array}$ & $\begin{array}{l}3,09 \\
2,87 \\
2,83 \\
2,44\end{array}$ & 0,002 & $\begin{array}{l}3,16 * \\
3,65 \\
3,64 \\
3,99 *\end{array}$ & 0,002 & $\begin{array}{l}3,69 \\
3,87 \\
3,83 \\
3,52\end{array}$ & 0,210 & $\begin{array}{l}4,40 \\
4,17 \\
4,37 \\
4,16 \\
\end{array}$ & 0,094 & $\begin{array}{l}3,70 \\
3,72 \\
3,60 \\
3,27\end{array}$ & 0,135 \\
\hline$\stackrel{\bar{\Xi}}{\bar{E}}$ & $\begin{array}{l}1 \\
2 \\
3 \\
4\end{array}$ & $\begin{array}{l}2,78 \\
2,79 \\
2,95 \\
2,66^{*}\end{array}$ & 0,011 & $\begin{array}{l}3,65 \\
3,69 \\
3,61 \\
3,69\end{array}$ & 0,841 & $\begin{array}{l}3,96 \\
384 \\
3,76 \\
2,37 *\end{array}$ & 0,001 & $\begin{array}{l}4,29 \\
4,20 \\
4,40 \\
4,16 \\
\end{array}$ & 0,247 & $\begin{array}{l}3,77 \\
3,62 \\
3,52 \\
3,48\end{array}$ & 0,073 \\
\hline $\begin{array}{l}\bar{n} \\
\overline{\bar{n}} \\
\tilde{n} \\
\check{\pi}\end{array}$ & $\begin{array}{l}\text { Illk } \\
\text { Ortanca } \\
\text { Son }\end{array}$ & $\begin{array}{l}2,85 \\
2,77 \\
2,88\end{array}$ & 0,309 & $\begin{array}{l}3,68 \\
3,58 \\
3,65\end{array}$ & 0,500 & $\begin{array}{l}3,95^{*} \\
3,72 \\
3,72\end{array}$ & 0,011 & $\begin{array}{l}4,14^{*} \\
4,32 \\
4,43\end{array}$ & 0,043 & $\begin{array}{l}3,68 \\
3,65 \\
3,60\end{array}$ & 0,454 \\
\hline 兰 & $\begin{array}{l}\text { Düşük } \\
\text { Orta } \\
\text { Yüksek }\end{array}$ & $\begin{array}{l}2,83 \\
2,85 \\
2,73 \\
\end{array}$ & 0,713 & $\begin{array}{l}3,49 \\
3,79 \\
4,03 *\end{array}$ & 0,001 & $\begin{array}{l}3,65 \\
3,91 * \\
3,63\end{array}$ & 0,03 & $\begin{array}{l}3,21 \\
3,38 \\
3,75^{*}\end{array}$ & 0,007 & $\begin{array}{l}3,42 \\
3,72 \\
3,75^{*}\end{array}$ & 0,003 \\
\hline
\end{tabular}




\section{Tartışma}

Bu çalıșmada Covid-19 salgını nedeniyle Türkiye'de 65 yaş üzeri ve 20 yaș altı için sokağa çıkma yasağının olduğu bir dönemde, üniversite öğrencilerinin sosyal medya bağımlılı̆̆ ve temel psikolojik intiyaçlarının karșılanma düzeyi arasındaki ilişki incelenmiş ve sonuç olarak değişkenler arasında negatif yönlü ilișki bulunmuștur. Üniversite öğrencilerinin psikolojik intiyaçlarııın karşılanma düzeyleri arttığında, sosyal medyaya olan bağımlılık düzeyleri azalmaktadır. Psikolojik intiyaçlarının karșılanma düzeyi düștüğünde ise sosyal medyaya olan bağımlılık düzeylerinde artış olmaktadır. Katılımcılar Covid-19 sürecinde sosyal medya kullanımlarının arttığını ifade etmișlerdir. Kullanım sürelerindeki artışa göre sosyal medya bağımlılık düzeyleri değerlendirildiğinde: Salgın sürecinde sosyal medya kullanımının 8 saat ve daha fazla arttığını belirten katıımcıların diğer katılımcılara göre bağımlılık düzeylerinin anlamlı olarak daha yüksek olduğu belirlenmiștir.

Madde bağımlılıklarında olduğu gibi (35) internet tabanlı bağımlılıklardaki artışta da olumsuz çevre koşullarının etkisi göz ardı edilemez bir durumdur (10). Pandemi döneminde Hindistan'da insanların \%87'sinin (5), Çin'in Vuhan kentinde ise \%80'den fazlasının (36) sosyal medya kullanımının arttığı bildirilmiștir. Araştırma katılımcılarının \%82,9 gibi büyük bir oranı, pandemi sürecinde sosyal medya kullanım sürelerinin pandemi öncesine göre arttığını ifade etmișlerdir. Bu dönemde sosyal medya kullanım sürelerinin arttığını ifade edenlerin sosyal medya bağımlılık düzeyleri de yüksek bulunmuștur.

Araștırmanın amaçlarından biri de Covid-19 salgının sürecinde üniversite öğrencilerinin psikolojik ihtiyaçlarının karşılanma düzeyini incelemekti. Katılımcılar salgın sürecinde temel psikolojik ihtiyaçlarının genel olarak yüksek düzeyde karșılandığını ifade etmektedir. Covid-19 kısıtlamaları sürecinde, psikolojik intiyaçların yüksek oranda karșılanması, araştırmanın beklenmeyen bir bulgusu olmuștur. Bu bulgu, "Psikolojik ihtiyaçların gerçek yașamda yeterince karșılanamadığı dönemlerde, kişiler sosyal medyayı bu intiyaçlarını karşılamak için telafi edici bir araç olarak kullanıyor olabilir mi?" sorusunu akla getirmektedir. Nitekim, bazı araștırmalar temel psikolojik intiyaçlar ile sosyal medya kullanımı arasında bağlantı olduğunu göstermektedir. Yine diğer bazı araştırmalar da insanların sosyal ağları; suçluluk, kaygı, çaresizlik ve depresyon gibi olumsuz duygularını azaltmak, kișisel sorunlarını unutmak (ruh hali değișikliği) için de bağımlılı̆̆a yol açacak șekilde kullanabildiklerini göstermektedir (37-40).

Araștırmanın bir diğer bulgusuna göre sosyal medya bağımlılığı yüksek düzeyde olan öğrenciler, sosyal medyayı belirli bir zaman dilimi olmaksızın tüm gün kullanmaktadır. Bilindiği üzere sosyal medya bağımlılığının en önemli kriterlerinden biri, sosyal medya ağlarında sürekli çevrimiçi kalma isteğidir
(13). Griffiths de bu konuya dikkat çekmiş ve kişilerin sosyal medyayı kullandığında, hissettikleri ve ruh halini değiştiren bazı etkilere tekrar ulaşabilmek amacıyla, burada harcadıkları zamanı kademeli olarak artırdığı süreci, sanal tolerans olarak tanımlamışır (41). Alan yazında haftalık internet kullanım süresi ile bağımlılık arasında ilişki kuran bazı yayınlar; haftalık 39 saat, bazıları 21 saat, bazıları ise 9 saat kullanımı önemli bir bağımlılık kriteri olarak tanımlamaktadır (42). Araştırmamıza katılan öğrencilerin \%48'i 1-3 saat arası, \%36'sı 4-6 saat arası ve $\% 8,7$ 'si ise 7 saat ve daha fazla sürelerde günlük olarak sosyal medya kullandığını bildirmiștir. Bu oranlara göre, katılımcıların sosyal medya bağımlılık düzeylerinin yüksek olduğu söylenebilir.

Araştırmaya üniversite öğrencilerinin dahil edilmesinin önemli nedenlerinden biri, eğitimli ve genç yaştaki kişilerde internet tabanlı bağımlııkların daha yaygın görüldüğüne yönelik bazı araştırma bulgularının olmasıydı. Sosyal medya bağımlıığının toplumlara göre yaygınlık oranlarıyla ilgili alan yazında $\% 2,8$ ile \%47 arasında değișen bulgular mevcuttur (43). Araștırmamızın bulgularına göre ise üniversite öğrencilerinin \%17,9'ununda sosyal medya bağımlılığı düzeyi yüksek düzeyde, \%53,3' ünün orta düzeydedir.

Demografik özelliklerle sosyal medya bağımlılığı arasında da önemli bir ilișki vardır. Geçmiște yapılan bazı araștırmalarda, erkek kullanıcıların sosyal medya bağımlılığı düzeyinin kadın kullanııılara göre daha yüksek olduğu yönünde bulgular mevcuttur. Ancak gerek son yapılan araștırmalar ve geniş çaplı meta-analiz çalıșmaları $(43,44)$ gerekse araștırmamızın bulguları, kadınların sosyal medya bağımlılığı düzeyinin erkelerden daha fazla olduğunu göstermektedir. Araştırma verilerimiz yaşın ilerlemesiyle birlikte sosyal medya bağımlığının azaldığını da göstermektedir. Bu bulgu diğer araștırma bulguları ile örtüşmektedir (45).

Sosyal medya sitelerinde aranan psikolojik doyumlar ile sosyal medya kullanım alışkanlıkları arasında pozitif ilişki olduğunu gösteren bazı araştırma bulguları vardır (46). Bu çalışmada da sosyal medya bağımlılığı ve temel psikolojik intiyaçların karşılanma düzeyinin, öğrencilerin sosyal medyayı kullanım alışkanlıklarına göre farklılaşı̆ı̆ı görülmektedir. Eğlence ve özgürlük ihtiyacının daha düşük düzeyde karşılandığı kişiler, sosyal medyayı öğle vakitlerinde; güç ihtiyacının daha düşük düzeyde karșılandığı kişiler ise sabah vakitlerinde daha fazla kullanmaktadır. Güç ihtiyacı yüksek düzeyde karșılanan kişilerin sosyal medya kullanımlarının daha az olduğu görülmektedir. Bu durum sosyal medyanın bazı insanların kendini güçlü hissetme ihtiyacının karșılanmasına aracılık ettiği şeklinde yorumlanabilir. Nitekim sosyal medya araçlarının tasarımı, tıpkı video oyunları gibi kullanıcıların kendilerini sanal ortamda da olsa güçlü hissetmelerini sağlayacak bazı özelliklere sahiptir. Dijital çağda insanlar; prestij kazanma, saygı görme, yarıșma, şöhret ve kendini önemli hissetme gibi güçlülük unsurlarını artık 
sosyal ağlarda elde edilen; beğeni, takipçi ve arkadaş sayıları ya da mavi tik onayı ile de ölçer hale gelmiştir. Bu konuda literatürde spesifik bir araștırma bulgusuna rastlanmamıștır ve yeni yapılacak araştırmalara fikir verebileceği düşünülmektedir.

Sosyal medya bağımlılığının temel psikolojik ihtiyaçlarla ilișkisini inceleyen araștırmamız, alan yazında bu konuda sınırlı sayıda yapılan çalışmalardan biri olmakla birlikte bazı kısıtlılıkları da söz konusudur. Her şeyden önce sosyal medya bağımlılığı kavramının DSM-5’te resmi bir tanı olarak yer almaması araștırmanın önemli sınırlılıklarından biridir. Ayrıca araştırmada katılımcıların Covid-19 sürecinden etkilenme düzeyi ve sosyal medya kullanım oranları hakkındaki veriler, kendi beyanları esas alınarak ve önceki durumları bilinmeden değerlendirilmiștir. Salgın kısıtlamalarının örneklem üzerindeki etkileri incelenirken anketlerin uygulandı̆̆ı dönemde örneklemin kısıtlama kurallarına uyduğu varsayılmıștır.

Sonuç olarak, üniversite öğrencilerinin sosyal medya bağımlılığının düzeyi ile psikolojik ihtiyaçlarının karşılanma düzeyi arasında ilişki olduğunu gösteren bu araștırmanın bulguları, gerek problemli internet kullanımının gerekse sosyal medya bağımlılığının önlenmesi için önemli faydalar sağlayabilir. Özellikle de üniversite öğrencilerinin \%17,9'unun sosyal medya bağımlılığının yüksek düzeyde olduğu yönündeki bulgumuzun üzerinde önemle durulmalıdır. Sosyal medyanın, üniversite öğrencileri tarafından bu denli yoğun şekilde kullanımının, öğrencilerin kariyer hedeflerini olumsuz yönde etkileyeceği ortadadır. Bu nedenle, bazı kişilerin sosyal medyaya diğerlerine göre neden daha fazla yöneldikleri, sosyal medya bağımlılı̆̆ını önlemede ve var olan internet tabanlı bağımlılıkların çözümünde psikolojik ihtiyaçların rolü gibi konularda yeni araștırmalara ihtiyaç vardır.

\section{Kaynaklar}

1. Wood M, Center H, Parenteau SC. Social media addiction and psychological adjustment: religiosity and spirituality in the age of social media, Ment Health Relig Cult 2016; 19(9): 972-983.

2. Quan-Haase A, Young AL. Uses and gratifications of social media a comparison of facebook and instant messaging. Bull Sci Technol Soc 2010; 30(5): 350-361.

3. Weare Social Digital 2021. https://wearesocial.com/digital-2021 (22.05.2021 tarihinde ulaşıldı)

4. Gençer AG, Karadere ME, Okumuş B, Hocaoğlu Ç. DSM-5'e giremeyen tanılar (kompulsif satın alma, misophonia, facebook kıskançlı̆̆ı, pagofaji, siberkondria, internet bağımlılı̆̆ı). DSM-5'in yeni tanıları. Hocaoğlu Ç (Ed.), Ankara, Türkiye Klinikleri 2018; 87-96.

5. Singh S, Dixit A, Joshi G. Is compulsive social media use amid Covid-19 pandemic addictive behavior or coping mechanism? Asian J Psychiatr 2020; 54: 102290 .

6. Nowland R, Necka EA, Cacioppo JT: Loneliness and social internet use: pathways to reconnection in a digital world? Perspect Psychol Sci 2018; 13(1): $70-87$.
7. Meshi D, Ellithorpe, ME. Problematic social media use and social support received in real-life versus on social media: Associations with depression, anxiety and social isolation. Addict Behav 2021; 119: 106949.

8. Balakrishnan V, Shamim A. Malaysian facebookers: Motives and addictive behaviours unraveled. Comput Human Behav 2013; 29(4): 1342-1349.

9. Ryan T, Chester A, Reece J, Xenos S. The uses and abuses of facebook: A review of facebook addiction. J Behav Addict 2014; 3(3): 133-148.

10. Cheng C, Li AYL. Internet addiction prevalence and quality of (real) life: A meta-analysis of 31 nations across seven world regions. Cyberpsychol Behav Soc Netw 2014; 17(12): 755-760.

11. Kuss DJ, Lopez-Fernandez 0 . Internet addiction and problematic internet use: A systematic review of clinical research. World J Psychiatry 2016; 6(1): 143-176.

12. Evren C, Dalbudak E, Evren B, Demirci Çiftci, A. High risk of internet addiction and its relationship with lifetime substance use, psychological and behavioral problems among 10th grade adolescents. Psychiatr Danub 2014; 26(4): 330-339.

13. Andreassen CS, Pallesen S. Social network site addiction-an overview. Curr Pharm Des 2014; 20(25): 4053-4061.

14. Katz E, Blumler JG, Gurevitch M. The Uses Of Mass Communications: Current Perspectives On Gratifications Research. Beverly Hills, Sage Publications, 1974.

15. Abbas R, Mesch GS. Cultural values and facebook use among Palestinian youth in Israel. Comput Human Behav 2015; 48(C) :644-653.

16. Taş HY, Kaçar S. X, Y ve Z kuşağı çalıșanlarının yönetim tarzları ve bir işletme örneği. OPUS Int J Society Res 2019; 18(11): 642-675.

17. Aktan E. Üniversite öğrencilerinin sosyal medya bă̆ımlılık düzeylerinin çeșitli değișkenlere göre incelenmesi. Erciyes Illetişim Dergisi 2018; 5(4): 405421.

18. Skierkowski D, Wood RM. To text or not to text? The importance of text messaging among college-aged youth. Comput Human Behav 2012; 28(2): 744-756.

19. Tsai HF, Cheng SH, Yeh TL, et al. The risk factors of internet addiction: A survey of university freshmen. Psychiatry Res 2009; 167(3): 294-299.

20. Suler JR. To get what you need: Healthy and pathological internet use. Cyberpsychol Behav 2009; (2)5: 385-393.

21. Koç M. İnternet addiction and psychopathology. TOJET: The Turkish Online Journal of Educational Technology 2011; 10(1): 143-148.

22. Akpınar 0, Öz FS. Gerçeklik terapisi: Özellikler, temel kavramlar, tedavi, uygulama ve değerlendirme.Electronic J Soc Sci 2013; 12(43): 1-22.

23. Baumeister RF, Leary MR. The need to belong: Desire for interpersonal attachments as a fundamental human motivation. Psychol Bull 1995; 117(3): 497-529.

24. Peterson AV. Choice theory and reality therapy. Tennessee Couns Assoc I 2000; 28(1): 41-50

25. Yorgun A, Acar VN. The practicality of reality therapy in Turkish culture: an analytical overview. Education and Science 2014; 39(175): 216-226.

26. Sarhangpour H, Baezzat F. Predicting cyberloafing through psychological needs with conscientiousness and being goal-oriented as mediators among university students. Int J Psychol 2018; 12(2): 147-168.

27. Kaner S. Kontrol kuramı ve gerçeklik terapisi. Ankara Üniversitesi Eğitim Bilimleri Fakültesi Dergisi 1993; 26(2): 569-585.

28. Deci, EL, Ryan RM. The "what" and "why" of goal pursuits: human needs and the self-determination of behavior. Psychol Inquiry 2000; 11(4): 227-268 
29. Overholser JC. A simulated interview with William Glasser: Part 1-An ideology about mental health. Irish Association for Counselling and Psychotherapy 2019; 19(3): 4-8

30. Yardımcı İ. Mizah kavramı ve sanattaki yeri. Ușak Üniversitesi Sosyal Bilimler Dergisi 2010; 3(2): 1-41.

31. Young-Ju J, Ae-Kyung C, Jeong-Jin K, Min-Yeong L. Identification of the structural relationship of basic psychological needs and facebook addiction and continuance. The Journal of the Institute of Internet, Broadcasting and Communication 2016; 16(1): 183-191.

32. Şahin C, Yağcı M. Sosyal medya bağımlılığı ölçeği-yetişkin formu: Geçerlilik ve güvenirlik çalıșması. Ahi Evran Üniversitesi Kırșehir Eğitim Fakültesi Dergisi 2017; 14(1): 523-538.

33. Türkdoğan T, Duru E. Üniversite öğrencileri temel ihtiyaçlar ölçeğinin (ÜÖTiÖ) geliștirilmesi: Geçerlik ve güvenirlik çalıșması. Pamukkale Üniversitesi Eğitim Fakültesi Dergisi 2012; 31(1): 81-91.

34. Tabachnick BG, Fidell LS. Using Multivariate Statistics. (6h Ed.) Boston: Person Education, 2012

35. Bulut S, Bozkurt I. The effect of treatment motivation levels on patients sent to a conditional substance abuse treatment program. Universitas Psychologica 2019; 18(1): 1-16.

36. Gao J, Zheng P, Jia Y, et al. Mental health problems and social media exposure during COVID-19 outbreak. PLoS One 2020; 15(4): e0231924.

37. Andreassen CS. Online social network site addiction: A comprehensive review. Curr Addict Rep 2015; 2015(2): 175-184.

38. Clark M, Calleja K. Shopping addiction: A preliminary investigation among Maltese university students. Addict Res Theory 2008; 16(6): 633-649.
39. Vansteenkiste M, Ryan RM. On psychological growth and vulnerability: Basic psychological need satisfaction and need frustration as a unifying principle. J Psychother Integr 2013; 23(3): 263-280.

40. Dongping L, Wenhua Z, Xian L et al. Stressful life events and adolescent internet addiction: The mediating role of psychological needs satisfaction and the moderating role of coping style. Comput Human Behav 2016; 63(C): 408-415.

41. Griffiths, M. A components model of addiction within a biopsychosocial framework. J Subst Use 2005; 10(4): 191-197.

42. Van den Eijnden RJJM, Meerkerk GJ, VermulstAA, et al. Online communication, compulsive internet use, and psychosocial well-being among adolescents: A longitudinal study. Dev Psychol 2008; 44(3): 655-665.

43. Andreassen CS, Joel Billieux J, Griffiths MD, et al. The relationship between addictive use of social media and video games and symptoms of psychiatric disorders: A large-scale cross-sectional study. Psychol Addict Behav 2016; 30(2): 252-262.

44. Banyai F, Zsila A, Kiraly O, et al. Problematic social media use: Results from a large-scale nationally representative adolescent sample. PLoS One 2017; 12(1): e0169839

45. Ho SS, Lwin M, Lee, E. Till logout do us part? Comparison of factors predicting excessive social network sites use and addiction between Singaporean adolescents and adults. Comp Human Behav 2017; 75: 632-642.

46. Chen HT, Kim, Y. Problematic use of social network sites: The interactive relationship between gratifications sought and privacy concerns. Cyberpsychol Behav Soc Netw 2013; 16(11): 806-812. 